\title{
Below-ground plant-soil interactions affecting adaptations of rice to iron toxicity
}

\author{
Guy J. D. Kirk ${ }^{1}$ ( ) | Hanna R. Manwaring ${ }^{1}$ | Yoshiaki Ueda ${ }^{2}$ @ | \\ Vimal K. Semwal ${ }^{3}$ (ㄴ) | Matthias Wissuwa ${ }^{2}$ (ㅇ
}

${ }^{1}$ School of Water, Energy and Environment, Cranfield University, Cranfield, UK

${ }^{2}$ Crop, Livestock and Environment Division, Japan International Research Center for Agricultural Sciences, Tsukuba, Japan

${ }^{3}$ Africa Rice Center, c/o IITA, PMB 5320, Ibadan, Nigeria

\section{Correspondence}

Guy J. D. Kirk, School of Water, Energy and Environment, Cranfield University, Cranfield MK43 OAL, UK.

Email: g.kirk@cranfield.ac.uk

Funding information

Biotechnology and Biological Sciences

Research Council, Grant/Award Number: BB// R020388/1

\begin{abstract}
Iron toxicity is a major constraint to rice production, particularly in highly weathered soils of inland valleys in sub-Saharan Africa where the rice growing area is rapidly expanding. There is a wide variation in tolerance of iron toxicity in the rice germplasm. However, the introgression of tolerance traits into high-yielding germplasm has been slow owing to the complexity of the tolerance mechanisms and large genotype-by-environment effects. We review current understanding of tolerance mechanisms, particularly those involving below-ground plant-soil interactions. Until now these have been less studied than above-ground mechanisms. We cover processes in the rhizosphere linked to exclusion of toxic ferrous iron by oxidation, and resulting effects on the mobility of nutrient ions. We also cover the molecular physiology of below-ground processes controlling iron retention in roots and root-shoot transport, and also plant iron sensing. We conclude that future breeding programmes should be based on well-characterized molecular markers for iron toxicity tolerance traits. To successfully identify such markers, the complex tolerance response should be broken down into its components based on understanding of tolerance mechanisms, and tailored screening methods should be developed for individual mechanisms.

KEYWORDS

rice rhizosphere, root-soil interface, stress tolerance markers, submerged paddy soils
\end{abstract}

\section{1 | INTRODUCTION}

Iron toxicity refers to a set of severely yield-limiting disorders associated with high concentrations of reduced ferrous iron (Fe[II]) in submerged lowland rice soils (Becker \& Asch, 2005; Sahrawat, 2005). It is exclusively a problem of submerged soils, because the low redox potential associated with exclusion of $\mathrm{O}_{2}$ from the soil leads to the prevalence of reduced, soluble Fe(II), whereas in well-aerated soils, the dominant form is insoluble ferric iron (Fe[III]) (Figure 1). It is particularly a problem on highly weathered, nutrient-depleted soils rich in iron oxides. These typify much of the current and potential rice growing area in sub-Saharan Africa, in contrast to the young, fertile, alluvial soils of the Asian lowlands, where most rice research has been done. Hence iron toxicity has not been a priority in much of the international rice breeding effort. However, it is a major constraint to rice in sub-Saharan Africa. Estimates of the rice growing area in sub-Saharan Africa affected by iron toxicity vary from $20 \%$ to $60 \%$, and estimated yield losses vary from $10 \%$ to $90 \%$ (Rodenburg et al., 2014; Sikirou et al., 2015). Ironically, most of the global hotspots of iron toxicity in 
(a)

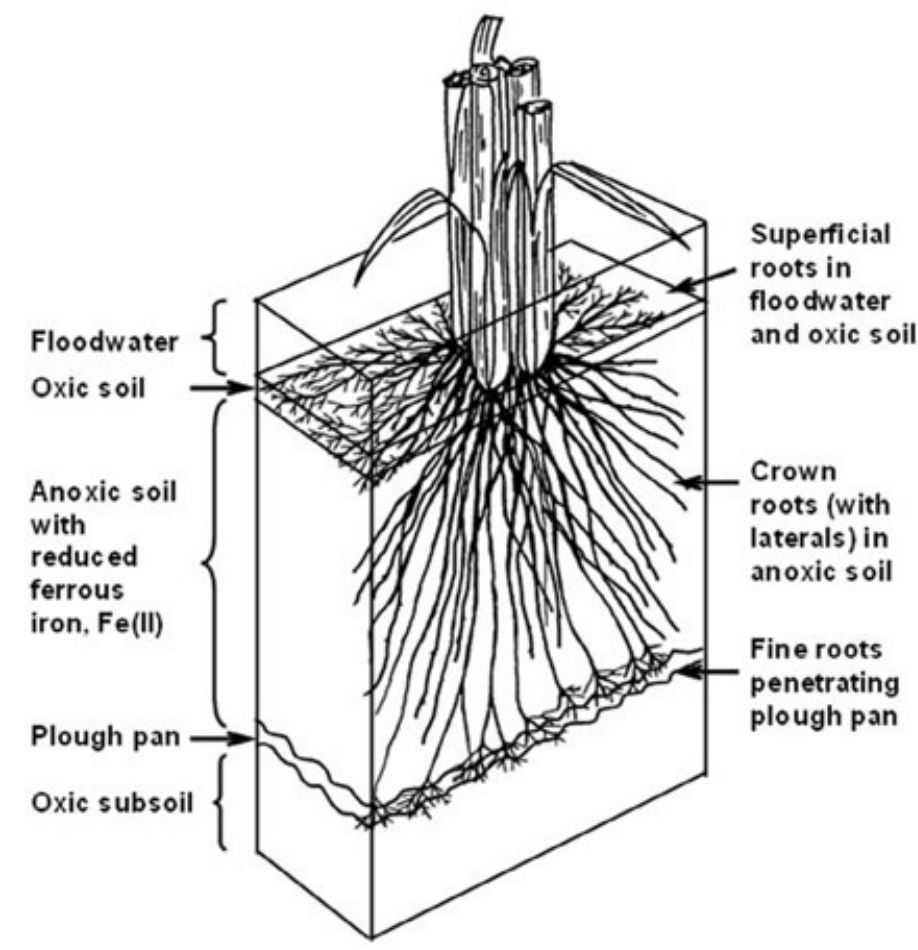

(b)

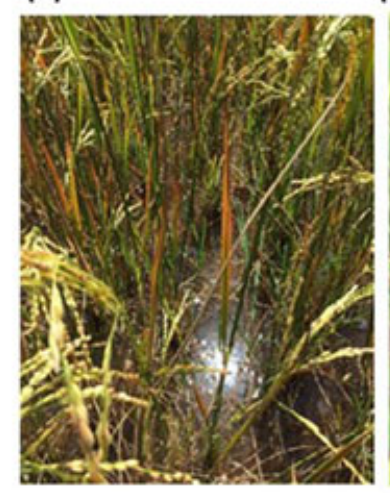

(c)

(d)

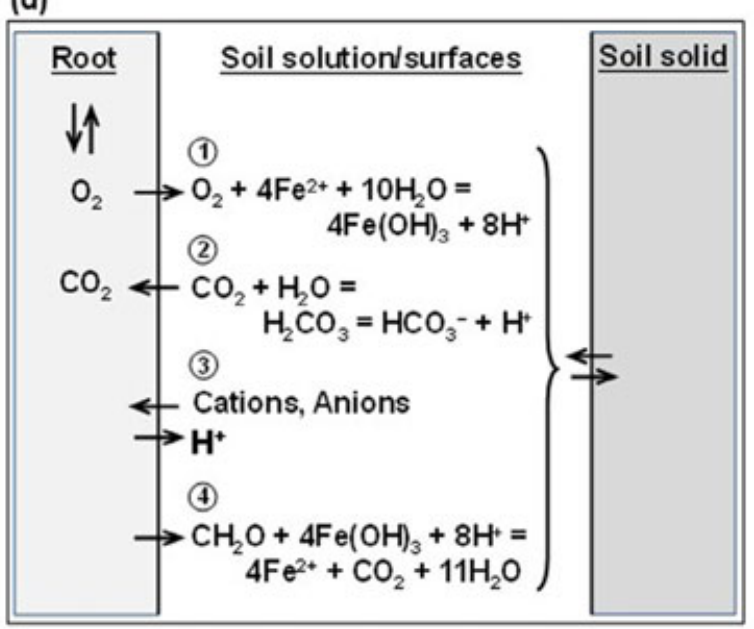

FIGURE 1 Below-ground environment and above-ground symptoms of rice in submerged iron toxic soil. (a) The root system and submerged soil profile. (b) Leaf bronzing and stunted growth due to iron toxicity. (c) Leaf bronzing and oranging due to iron toxicity with Mg deficiency. (d) Root effects on the soil: (1) oxidation of ferrous iron by $\mathrm{O}_{2}$ released from the roots; (2) venting of soil $\mathrm{CO}_{2}$ into the root aerenchyma and associated changes in soil carbonate equilibria; (3) excess intake by the root of nutrient cations (particularly ammonium, $\mathrm{NH}_{4}^{+}$) over anions and associated release of $\mathrm{H}^{+}$; (4) in the zone where there is no $\mathrm{O}_{2}$ release, re-reduction of ferric iron fuelled by organic substrates (represented as $\mathrm{CH}_{2} \mathrm{O}$ ) diffusing across leaky root membranes. Note the protons $\left(\mathrm{H}^{+}\right.$ions) consumed or produced in these reactions will be buffered by protondonating or -accepting groups in the soil solid [Colour figure can be viewed at wileyonlinelibrary.com]

rice overlap with areas where iron deficiency in human diets is acute, suggesting that rice varieties grown currently are not effective in translocating excessively-available iron from the soil into the grain (Frei et al., 2016).

There is a large variation in tolerance of iron toxicity in the rice germplasm, especially in the Oryza glaberrima species indigenous to West Africa (Sikirou et al., 2015), and in varieties of Oryza sativa indigenous to Madagascar (Rakotoson et al., 2019). Modern high-yielding varieties are far more susceptible to iron toxicity than locally adapted but low-yielding traditional varieties. If tolerance traits in the indigenous African germplasm could be incorporated into improved varieties, this could have a huge impact on African rice productivity and the sustainable expansion of rice-based farming into new areas, and hence on overall African food security. However, progress with breeding has been slow. Constraints include the complexity of the phenomenon and associated tolerance mechanisms (Figures 1 and 2), poor understanding of tolerance mechanisms and a lack of reliable genetic markers for marker-assisted selection. The importance of particular mechanisms varies with the type of iron toxicity, and there are multiple types and interactions with nutrient deficiencies.

Three distinct types of iron toxic soil are recognized (Becker \& Asch, 2005; Sahrawat, 2005):

1. acid sulphate soils in coastal plains and river deltas, in which there is also extreme acidity and aluminium toxicity;

2. clayey organic soils in swampy highland areas, in which the toxicity becomes acute later in the season as strongly reducing conditions develop, and so it tends to be less destructive; and

3. poor sandy to coarse-loamy soils in inland valleys, where there is upwelling of interflow water from adjacent highlands with highly weathered soils, and the toxicity lasts throughout the growing season.

As a result of sensitivity to the local hydrology, there is often large field-scale heterogeneity in toxicity and dependence on inter-annual variability in rainfall. Further, there are often also deficiencies of 
mineral nutrients, particularly phosphorus, potassium, calcium and magnesium (Figure 3). Mineral deficiencies both compound the iron toxicity and are exacerbated by it. Hence growth reduction and yield losses occur at widely differing iron concentrations in the plant, associated with different soil types and landscape positions and interactions with hydrology and nutrient levels.

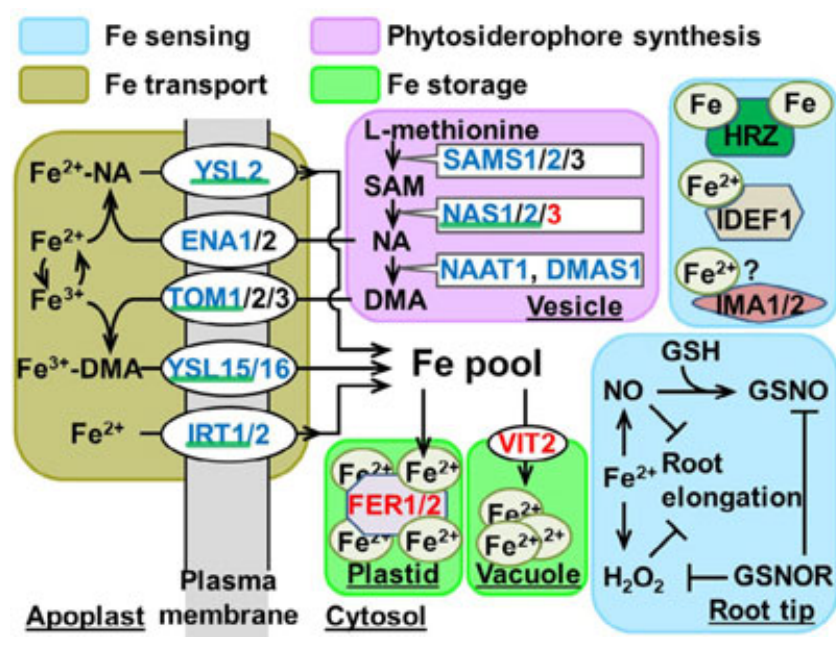

FIGURE 2 Iron sensing and regulation of iron uptake, storage and transport. Protein names in blue or red indicate gene expression is down- or up-regulated by iron excess, respectively; those underlined are controlled by the sensor protein HRZ. Arrows and T signs in the iron sensing box indicate positive and negative influences, respectively (as demonstrated in Arabidopsis). DMA, deoxymugineic acid; GSH, glutathione; GSNO, S-nitrosoglutathione; NA, nicotianamine; NO, nitric oxide; SAM, S-adenosyl methionine [Colour figure can be viewed at wileyonlinelibrary.com]
Germplasm screening for tolerance of iron toxicity is complicated by large genotype-by-environment effects linked to these multiple interactions. Plant adaptations to iron toxicity depend on complex below-ground plant-soil interactions. Above-ground symptoms are widely used for screening, but are generally only weakly correlated with yield losses (Sikirou et al., 2015) though there are exceptions to this (Audebert \& Fofana, 2009). Most work on tolerance mechanisms has been done in hydroponics, far removed from field reality, and there has been limited progress with the genetics of tolerance and gene mapping (Dufey et al., 2015; Matthus et al., 2015; Melandri et al., 2021; Pawar, Pandit, Mohanty, Saha, \& Pradhan, 2021; Sikirou et al., 2018). There is a need for an integrated approach to understand the mechanisms and genetics of iron toxicity tolerance, taking into account the complex below-ground plant-soil interactions. In this review, we focus on these below-ground processes, and interactions between genotype adaptations and mineral nutrient deficiencies. Above-ground tolerance mechanisms have recently been reviewed by Aung and Masuda (2020). Unless otherwise stated, results were obtained with Oryza sativa not Oryza glaberimma.

\section{2 | THE SOIL CHEMISTRY OF IRON TOXICITY}

The following is a summary of the changes in soil chemistry following submergence for lowland rice, taken from Kirk (2004). When a soil is submerged, air is excluded and the soil quickly becomes anoxic with the typical depth-profile shown in Figure 1a. Microbes must then use alternative end electron acceptors (oxidants) in oxidizing organic compounds for their energy needs. This proceeds roughly in the sequence predicted by thermodynamics:
FIGURE 3 Nutrient concentrations in rice in iron toxic soils with typical nutrient treatments. Data are for leaves or shoots during maximum tillering to flowering stages at inland valleys sites in Colombia (one site, one genotype, six nutrient treatments; Howeler, 1973), Côte d'Ivoire (two sites, three genotypes, two nutrient treatments; Sahrawat et al., 1996, Sahrawat, 2000), Indonesia (one site, one genotype, one nutrient treatment; Jugsujinda \& Patrick Jr., 1993), Madagascar (one site, five genotypes, three nutrient treatments; the authors, unpublished) and Nigeria (three sites, four genotypes, two nutrient treatments; M. Yamauchi, 1989). Boxes indicate 25th, 50th and 75th percentiles; whiskers 10th and 90th percentiles; red crosses are typical deficiency limits and iron and manganese toxicity limits (Dobermann \& Fairhurst, 2000) [Colour figure can be viewed at wileyonlinelibrary.com]
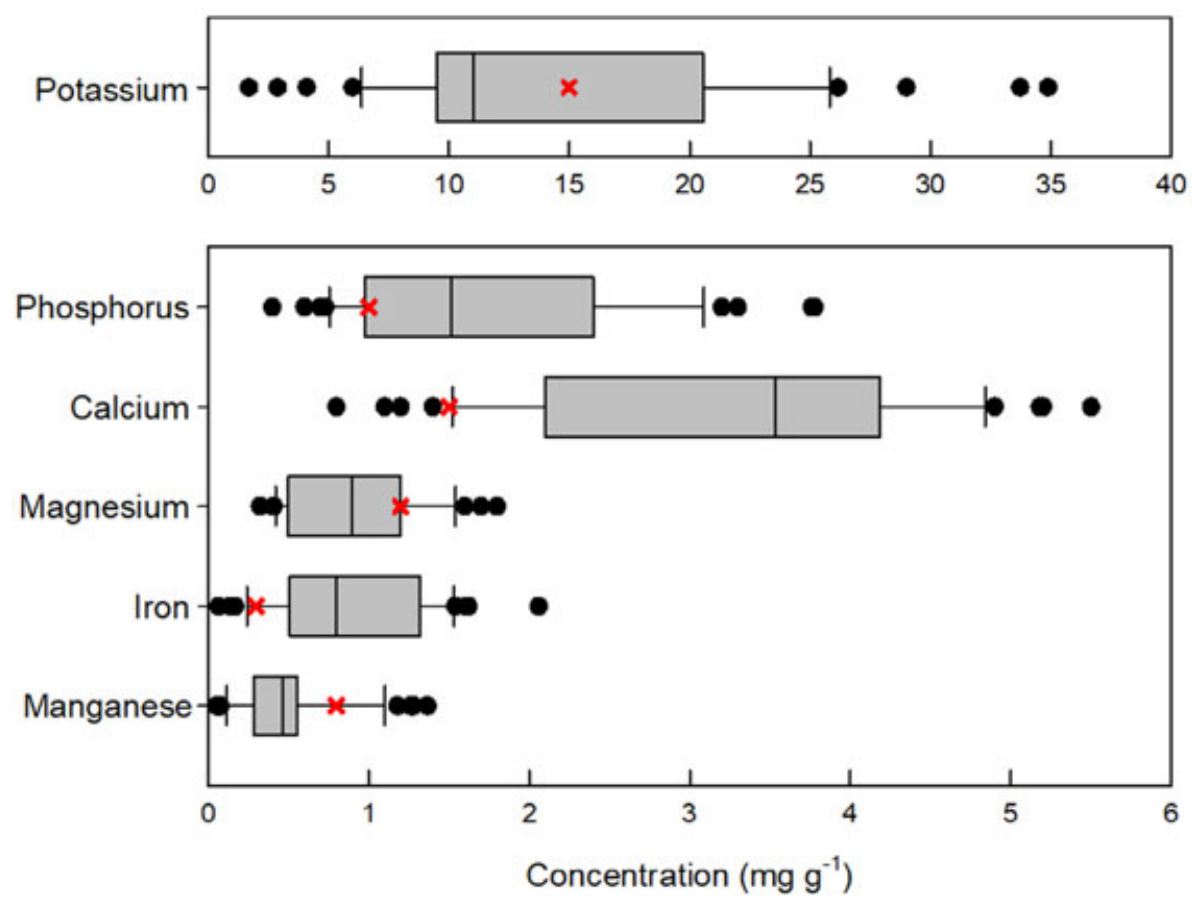


$$
\begin{gathered}
\mathrm{O}_{2}+\mathrm{CH}_{2} \mathrm{O} \rightarrow \mathrm{CO}_{2}+\mathrm{H}_{2} \mathrm{O} \\
4 \mathrm{NO}_{3}{ }^{-}+5 \mathrm{CH}_{2} \mathrm{O}+4 \mathrm{H}^{+} \rightarrow 2 \mathrm{~N}_{2}+5 \mathrm{CO}_{2}+7 \mathrm{H}_{2} \mathrm{O}, \\
2 \mathrm{MnO}_{2}+\mathrm{CH}_{2} \mathrm{O}+4 \mathrm{H}^{+} \rightarrow 2 \mathrm{Mn}^{2+}+\mathrm{CO}_{2}+3 \mathrm{H}_{2} \mathrm{O}, \\
4 \mathrm{Fe}(\mathrm{OH})_{3}+\mathrm{CH}_{2} \mathrm{O}+8 \mathrm{H}^{+} \rightarrow 4 \mathrm{Fe}^{2+}+\mathrm{CO}_{2}+11 \mathrm{H}_{2} \mathrm{O}, \\
\mathrm{SO}_{4}{ }^{2-}+2 \mathrm{CH}_{2} \mathrm{O}+2 \mathrm{H}^{+} \rightarrow \mathrm{H}_{2} \mathrm{~S}+2 \mathrm{CO}_{2}+2 \mathrm{H}_{2} \mathrm{O}, \\
2 \mathrm{CH}_{2} \mathrm{O} \rightarrow \mathrm{CH}_{4}+\mathrm{CO}_{2},
\end{gathered}
$$

where $\mathrm{CH}_{2} \mathrm{O}$ represents soil organic substrates and the alternative oxidants are oxygen $\left(\mathrm{O}_{2}\right)$, nitrate $\left(\mathrm{NO}_{3}{ }^{-}\right)$, manganese oxides $\left(\mathrm{MnO}_{2}\right)$, ferric hydroxide $\left(\mathrm{Fe}(\mathrm{OH})_{3}\right)$ and sulphate $\left(\mathrm{SO}_{4}{ }^{2-}\right)$. In the absence of $\mathrm{O}_{2}$, $\mathrm{Fe}(\mathrm{III})$ is generally the main oxidant in the soil, its concentration typically exceeding concentrations of $\mathrm{NO}_{3}{ }^{-}, \mathrm{MnO}_{2}$ or $\mathrm{SO}_{4}{ }^{2-}$ by at least an order of magnitude. Between $1 \%$ and $20 \%$ and sometimes as much as $90 \%$ of the free $\mathrm{Fe}(\mathrm{III})$ oxides in the soil are reduced to $\mathrm{Fe}(\mathrm{II})$ over 1-2 months of submergence. Some of the structural Fe(III) in soil clays is also reduced. The course of soil reduction and the changes in redox and $\mathrm{pH}$ are therefore generally dominated by the reduction of $\mathrm{Fe}(\mathrm{III})$.

As reduction proceeds, $\mathrm{H}^{+}$ions are consumed in Reactions (2)(5) and the $\mathrm{pH}$ tends to increase. Simultaneously carbon dioxide $\left(\mathrm{CO}_{2}\right)$ is produced, but escapes from the soil only very slowly, and it therefore accumulates to high partial pressures. The accumulation of $\mathrm{CO}_{2}$ lowers the $\mathrm{pH}$ of alkaline soils and curbs the increase in $\mathrm{pH}$ of acid soils. As a result, the $\mathrm{pHs}$ of most soils tend to converge following submergence in the range 6.5-7. Large concentrations of $\mathrm{Fe}^{2+}$ ions develop in the soil solution in the weeks following flooding, often several $\mathrm{mM}$ or tens of $\mathrm{mM}$, balanced by bicarbonate $\left(\mathrm{HCO}_{3}{ }^{-}\right)$anions formed from dissolved $\mathrm{CO}_{2}$. The ion activity products of pure ferrous hydroxides, carbonates and other minerals are often exceeded 100 -fold. Evidently precipitation of these minerals is inhibited, probably as a result of adsorption of dissolved organic matter and other solutes onto nucleation sites. However, once a sufficient supersaturation has been reached there is a rapid precipitation of amorphous solid phases containing Fe(II), which may later re-order to more crystalline forms. The exact nature of the Fe(II) compounds formed is uncertain But there is evidence that mixed Fe(II)-Fe(III) hydroxides are formed, which have some of the observed properties of the solid phase $\mathrm{Fe}$ (II) found in reduced soils, including the greyish-green colours characteristic of reducing conditions.

However, in highly weathered iron toxic soils typical of inland valleys, reduction tends to be slower and the rise in $\mathrm{pH}$ causing precipitation of $\mathrm{Fe}$ (II) compounds is more gradual, so that the soil solution and exchange complex continue to be dominated by $\mathrm{Fe}^{2+}$ ions (Kirk, Solivas, \& Alberto, 2003; Narteh \& Sahrawat, 1999; Ponnamperuma, 1972). A major factor in this is that such soils generally have large reserves of acidity, and so the soil $\mathrm{pH}$ remains below the neutral range in which the solubility products of the $\mathrm{Fe}$ (II) compounds are exceeded. Also, as a result of the acidity and slow reduction, concentrations of dissolved $\mathrm{CO}_{2}$ tend to be smaller.

\section{3 | BASIC ADAPTATIONS TO IRON TOXICITY}

\section{1 | Root growth}

Growth of crown roots is inhibited under iron toxicity through decreased cell elongation and division, and lateral root initiation is also inhibited (M. Yamauchi \& Peng, 1995; Y. Zhang et al., 2011). A smaller root surface area will tend to restrict nutrient absorption, but root growth will also respond to the plant nutrient status (Section 5).

To the extent that there is a gradient of reducing conditions and $\mathrm{Fe}^{2+}$ concentration with depth through the soil, concentration of root growth at shallower depths might prevent serious iron toxicity and allow controlled acclimation to nutritional stress (G. Li, Kronzucker, \& Shi, 2016a). Supporting this, lateral root formation on crown roots is unaffected by exposure of the crown root tip to high concentrations of $\mathrm{Fe}^{2+}$. When the root tip is exposed to $\mathrm{Fe}^{2+}$ stress, root gravitropism may change, favouring root expansion in shallower lesstoxic soil.

These effects result from direct contact of the root tip with high concentrations of $\mathrm{Fe}^{2+}$ (G. Li, Kronzucker, \& Shi, 2016b). Ethylene and reactive oxygen species (ROS) are involved in most abiotic stress responses, but it is unknown whether ethylene acts alone or in conjunction with ROS in the response of root tips to high $\mathrm{Fe}^{2+}(\mathrm{G}$. Li et al., 2016b). The root tip is also the primary sensing site for the effect on lateral root formation.

\section{2 | Root morphology and ferrous iron exclusion}

Iron exclusion by oxygenation of the rhizosphere is a principal adaptation to iron toxic soils. Because of the very slow diffusion of respiratory gases through water and submerged soil, rice roots must develop an efficient internal aeration system to deliver $\mathrm{O}_{2}$ to submerged tissues and vent respiratory $\mathrm{CO}_{2}$ in the opposite direction. As a root elongates, the cortex degrades forming a network of interconnected gas channels - aerenchyma - connected to lacunae at the shoot base (T. Yamauchi, Colmer, Pederson, \& Nakazono, 2018). Oxygen enters from the atmosphere above and diffuses through the aerenchyma to root tissues. In addition, the roots contain a barrier to radial $\mathrm{O}_{2}$ loss in the basal zones. The barrier restricts $\mathrm{O}_{2}$ loss, and thereby permits a greater length of root to be aerated. However, particularly in iron toxic soils, some degree of $\mathrm{O}_{2}$ loss to the rhizosphere is permitted to exclude $\mathrm{Fe}^{2+}$ by oxidizing it to ferric hydroxide, and possibly for other aerobic processes in the rhizosphere.

Rice genotypes differ in their $\mathrm{Fe}^{2+}$ excluding powers, due to differences in aerenchyma formation, barriers to radial $\mathrm{O}_{2}$ loss and enzymatic $\mathrm{Fe}^{2+}$ oxidation power (Ando, Yoshida, \& Nishiyama, 1983; Engel, Asch, \& Becker, 2012; Mongon, Konnerup, Colmer, \& Rerkasem, 2014; T. Yamauchi et al., 2018). Aerenchyma formation is both 'constitutive' and responsive to environmental conditions (Nishiuchi, Yamauchi, Takahashi, Kotula, \& Nakazono, 2012). Ethylene signalling has been implicated in the flood-induced enhancement of 
aerenchyma formation, with the involvement also of hydrogen peroxide $\left(\mathrm{H}_{2} \mathrm{O}_{2}\right)$ in the programmed cell death that forms the lacunae in shoots (T. Yamauchi et al., 2018). Wu et al. (2014) reported a Quantitative Trait Locus (QTL) for iron toxicity tolerance on Chromosome 3 associated with $\mathrm{Fe}^{2+}$ exclusion via a greater density of fine lateral roots.

There is potentially a conflict between the rooting characteristics required for internal aeration and those for $\mathrm{Fe}^{2+}$ exclusion and efficient nutrient acquisition. Efficient nutrient uptake and $\mathrm{Fe}^{2+}$ exclusion are favoured by a large external root surface area (but see Section 4.2 for potential negative effects of root exclusion on nutrient uptake), whereas efficient internal aeration requires the opposite. Kirk (2003) developed a model for exploring this, based on steady-state diffusion of $\mathrm{O}_{2}$ through a crown root and its laterals and the simultaneous consumption of $\mathrm{O}_{2}$ in root respiration and loss to the soil. This showed, for a realistic set of parameter values - including rates of $\mathrm{O}_{2}$ loss to the soil at typical rates of $\mathrm{Fe}^{2+}$ oxidation in the rhizosphere - a system of coarse, aerenchymatous, crown roots with gas-impermeable walls conducting $\mathrm{O}_{2}$ to short, fine, gas-permeable laterals provided the greatest absorbing surface per unit aerated root mass. This is the basic architecture of current rice genotypes.

\section{3 | Membrane selectivity}

Ferrous iron breaching the oxidation zone in the rhizosphere enters the root apoplast by diffusion and mass flow in the transpiration stream. To reach the xylem for transport to the shoot, $\mathrm{Fe}^{2+}$ ions in the apoplast must bypass the Casparian strip in the endodermis by crossing cell membranes into the symplasm. This provides a potential exclusion mechanism, at least in undamaged roots. Up to $87 \%$ of the $\mathrm{Fe}^{2+}$ entering the root apoplast in mature plants is prevented from reaching the xylem at the endodermal barrier (Yamanouchi \& Yoshida, 1981). Exclusion at the plasma membranes is strongly affected by respiration inhibitors, high $\mathrm{Fe}^{2+}$ concentrations and nutrient stresses (Yoshida, 1981). Therefore, it is unlikely to be important under sustained severe toxicity (Becker \& Asch, 2005) so other mechanisms of root retention must operate.

Rice is unusual in graminaceous species in possessing $\mathrm{Fe}^{2+}$ transporters, OsIRT1 and OsIRT2, in addition to the usual genes for the synthesis and secretion of $\mathrm{Fe}(\mathrm{III})$-chelating phytosiderphores (Bughio, Yamaguchi, Nishizawa, Nakanishi, \& Mori, 2002; Ishimaru et al., 2006; Quinet et al., 2012). Transport of $\mathrm{Fe}^{2+}$ in the xylem involves complexation with nicotianamine (NA) and mugineic acid (MA). These are synthesized from L-methionine via S-adenosylmethionine, and rice possesses three $\mathrm{S}$-adenosylmethionine synthetase genes (OsSAMS13) (W. Li, Han, Tao, \& Chong, 2011), three NA synthase genes (OsNAS1-3) (Inoue et al., 2003), six NA amino-transferase genes (OsNAAT1-6) (Inoue et al., 2008) and one deoxymugineic acid (DMA) synthase gene (OsDMAS1) (Bashir, Ishimaru, \& Nishizawa, 2012). Secretions of NA and DMA into the rhizosphere are via OsENA1/2 and OsTOM1-3, respectively (Nozoye et al., 2011, 2015), and the resultant Fe(II)-NA and Fe(III)-DMA complexes are taken up via
OsYSL2 and OsYSL15/16 transporters (Inoue et al., 2009; Kakei et al., 2012; Koike et al., 2004). Microarray analyses suggest that expression of the genes involved in $\mathrm{Fe}^{2+}$ uptake, phytosiderophore biosynthesis and secretions and chelated Fe(III) uptake are all suppressed under different levels of iron excess, with the exception of OsNAS3 which is up-regulated (Aung, Masuda, Kobayashi, \& Nishizawa, 2018; Finatto et al., 2015; Quinet et al., 2012; Figure 2). The iron-binding ubiquitin ligase Haemerythrin motif-containing Really Interesting New Gene (RING)- and Zinc-finger (HRZ) protein is partially involved in the regulation of this process (Aung, Masuda, et al., 2018). It is suggested that up-regulation of OsNAS3 allows chelation of excess $\mathrm{Fe}^{2+}$ and controlled translocation to shoots for storage in stems or old leaves (Aung \& Masuda, 2020).

\section{4 $\quad$ Retention of iron in roots}

In healthy roots, most of the $\mathrm{Fe}^{2+}$ absorbed is retained in the roots in metabolically inactive forms (Yoshida, 1981). This is likely to involve sequestration in root cell vacuoles (Moore et al., 2014; Stein, Ricachenevsky, \& Fett, 2014) and in the ferritin protein in plastids (Briat et al., 2010; da Silveira et al., 2009; Stein, Ricachenevsky, \& Fett, 2009). The vacuolar $\mathrm{Fe}^{2+}$ transporter OsVIT2 (Y. Zhang, Xu, $\mathrm{Yi}, \&$ Gong, 2012) and rice ferritin genes OsFER1 and OsFER2 (Aung, Masuda, et al., 2018; Finatto et al., 2015; Quinet et al., 2012) are strongly up-regulated in roots and shoots by excess iron (Figure 2). Regulation of ferritin genes in response to iron excess occurs at the transcriptional level (Briat et al., 2010; Stein et al., 2009), and involves regulatory pathways mediated by abscisic acid (ABA), ROS and ethylene. However, Majerus, Bertin, and Lutts (2009) showed that in Oryza glaberrima a signalling pathway leading to the induction of ferritin synthesis depended on neither ABA nor ROS.

In plants taking up chelated Fe(III), increased apoplastic $\mathrm{pH}$ depresses ferric chelate reductase activity, restricting Fe(III) reduction to $\mathrm{Fe}(\mathrm{II})$ and thereby restricting $\mathrm{Fe}^{2+}$ mobility (Kosegarten et al., 2004). Failure to regulate apoplastic $\mathrm{pH}$ or supress ferric chelate reductase activity may result in uncontrolled accumulation of $\mathrm{Fe}^{2+}$ in shoots (Becker \& Asch, 2005). Acidification of the rhizosphere as a result of $\mathrm{Fe}^{2+}$ oxidation and excess cation over anion intake (Section 3.1) will tend to lower the $\mathrm{pH}$ in the root apoplast. The cation exchange capacity of root cell walls is also a factor. Cell wall components with negative surface charges (pectin and hemicelluloses) possess cation exchange sites, for which $\mathrm{Fe}^{2+}$ ions compete with other cations (G. Li et al., 2016b). The cation exchange capacity will decrease as the apoplastic $\mathrm{pH}$ decreases.

The effectiveness of these adaptations is limited by the $\mathrm{Fe}^{2+}$ storage capacity of root tissues, particularly towards the end of the growth cycle (Becker \& Asch, 2005). Wu, Ueda, Lai, and Frei (2017) studied the regulation of genes controlling iron uptake, partitioning and storage in a tolerant and a sensitive genotype in nutrient culture, and found no genotype differences in iron concentration and speciation in different plant tissues, nor in subcellular partitioning genes. 


\section{5 | Sensing of plant iron status}

Until now, the mechanisms of iron sensing in plants have mostly been investigated under iron deficient conditions rather than under iron excess. In both rice and Arabidopsis (Arabidopsis thaliana), a group of proteins containing the haemerythrin motif are involved in sensing iron deficiency. In rice, HRZ1/2 (OsHRZ1/2) proteins bind directly to iron and function as a molecular sensor for iron status (Kobayashi et al., 2013). Knockdown plants without these proteins are less susceptible to iron deficiency, probably because a basic helix-loop-helix (bHLH) transcription factor OsPRI1 is destabilized ( $\mathrm{H}$. Zhang, Li, Yao, Liang, \& Yu, 2017). Likewise, a homologue of OsHRZ1/2 in Arabidopsis, BRUTUS, negatively affects the stability of PRI1 homologues (Arabidopsis bHLH105/115) and so disrupts iron deficiency responses (Selote, Samira, Matthiadis, Gillikin, \& Long, 2015). This suggests that iron sensing mechanisms involving haemerythrin motif-containing proteins are conserved in higher plants.

Knockdown of OsHRZ2 leads to susceptibility to iron excess stress in rice (Aung, Kobayashi, Masuda, \& Nishizawa, 2018). Under excess iron, the OsHRZ2-knockdown plants had greater growth retardation, leaf bronzing and shoot iron concentrations than the wild-type plants. Correspondingly, the expressions of iron deficiency-inducible genes associated with iron uptake - such as OsNAS1/2, OsTOM1 and Yellow Stripe-Like 15 (OsYSL15) - were higher in the OsHRZ2 knockdown plants than the wild-type. Therefore, OsHRZ2 and probably OsHRZ1 are at least partly involved in sensing excess iron, and precise sensing of iron status by these proteins is likely to be important for iron toxicity tolerance.

Other components involved in sensing iron status have been elucidated, such as the transcription factor iron-deficiency-responsive elements factor 1 (IDEF1) in iron-binding graminaceous species (Kobayashi et al., 2007, 2012), and the IRON MAN (IMA) peptides found in flowering plants (Grillet, Lan, Li, Mokkapati, \& Schmidt, 2018; Kobayashi, Nagano, \& Nishizawa, 2021). The IDEF1 transcription factor binds $\mathrm{Fe}^{2+}$ ions via its His-Asp repeats and Pro-rich regions (Kobayashi et al., 2012). Over-expression of the homologue OsIDEF1 in rice leads to enhanced tolerance of iron deficiency (Kobayashi et al., 2007). Overexpression of the IMA homologue OsIMA1/2 triggers expression of many iron-deficiency-inducible genes involved in iron uptake (Kobayashi et al., 2021). In Arabidopsis, the IMA1 peptide binds divalent metal ions such as $\mathrm{Fe}^{2+}$, and lines in which IMA1 is overexpressed hyperaccumulate iron at normal iron concentrations and exhibit foliar necrotic symptoms, indicating iron toxicity (Grillet et al., 2018). It is not known if these iron-sensing mechanisms are functional under iron excess in rice and so linked with iron toxicity tolerance.

A recent Genome Wide Association Study (GWAS) on root shortening induced by excess iron and a subsequent mutant study revealed that S-nitrosoglutathione reductase (GSNOR) is involved in sensing iron status at the root tip (B. Li et al., 2019). The GSNOR gene alleviates iron-dependent production of nitric oxide and hydrogen peroxide, and resultant inhibition of root meristem growth. Naturally-occurring polymorphisms in the promoter region of GSNOR are associated with its expression level, and the allele of GSNOR with higher expression level confers tolerance. Rice mutants lacking homologues of GSNOR were more susceptible to iron excess, having impaired root elongation (B. Li et al., 2019). It is not known if naturally occurring alleles of GSNOR in rice could be used to increase the tolerance of currently grown rice cultivars to enhance biomass and grain yield.

\section{EFFECTS OF IRON TOXICITY ON MINERAL NUTRITION}

\section{1 | Root-induced change in the rhizosphere}

The following root-induced changes in the soil occur in the region of the root tip and along the length of fine laterals where the bulk of nutrient uptake happens (Figure $1 \mathrm{~d}$ ).

Ferrous iron oxidation. Oxygen diffusing down through a root's aerenchyma leaks out into the soil, which has a much lower $\mathrm{O}_{2}$ concentration. Mobile inorganic reductants in the soil are oxidized, particularly $\mathrm{Fe}^{2+}$ which is precipitated as $\mathrm{Fe}(\mathrm{OH})_{3}$ on or near the root (Begg, Kirk, Mackenzie, \& Neue, 1994). As a result, the concentration of $\mathrm{Fe}^{2+}$ near the root falls and more $\mathrm{Fe}^{2+}$ moves in from the bulk soil by diffusion and mass flow in the transpiration stream. This is then oxidized resulting in a zone of $\mathrm{Fe}(\mathrm{OH})_{3}$ accumulation over a few mm near the root. Each mol of $\mathrm{Fe}^{2+}$ oxidized generates $2 \mathrm{~mol} \mathrm{of} \mathrm{H}^{+}$ (Figure $1 \mathrm{~d}$ ), so the $\mathrm{pH}$ in the oxidation zone tends to fall. Away from the root tip, in zones where there is no release of $\mathrm{O}_{2}$ from the roots, $\mathrm{Fe}(\mathrm{OH})_{3}$ may be re-reduced to $\mathrm{Fe}^{2+}$ in anaerobic respiration fuelled by organic substrates released from the roots (Benckiser, Santiago, Neue, Watanabe, \& Ottow, 1984). This effect may be greater under nutrient deficiencies as a result of leaky root membranes, resulting in exacerbated iron toxicity.

$\mathrm{CO}_{2}$ uptake into roots. Large dissolved $\mathrm{CO}_{2}$ concentrations develop in submerged rice soils (equivalent partial pressures $5-70 \mathrm{kPa}$ - Greenway, Armstrong, \& Colmer, 2006; Kirk et al., 2019; Ponnamperuma, 1972) because $\mathrm{CO}_{2}$ formed in root and soil respiration escapes only slowly by diffusion through the water-filled soil pores. There is therefore a large $\mathrm{CO}_{2}$ gradient between the soil and the aerenchyma inside the root. Hence $\mathrm{CO}_{2}$ will enter the roots and be vented to the shoots and atmosphere by diffusion through the aerenchyma. Kirk et al. (2019) showed that $\mathrm{CO}_{2}$ venting through rice roots can be equivalent to a third of the daily $\mathrm{CO}_{2}$ fixation in photosynthesis. Net removal of $\mathrm{CO}_{2}$ decreases the concentration of the acid $\mathrm{H}_{2} \mathrm{CO}_{3}$ near the root, and this may offset the acidity produced in $\mathrm{Fe}^{2+}$ oxidation and excess cation uptake (Affholder, Weiss, Wissuwa, Johnson-Beebout, \& Kirk, 2017; Begg et al., 1994).

Proton release due to excess cation over anion intake. Because the main form of plant-available nitrogen in anaerobic soil is ammonium $\left(\mathrm{NH}_{4}{ }^{+}\right)$, the root absorbs an excess of nutrient cations $\left(\mathrm{NH}_{4}^{+}, \mathrm{K}^{+}, \mathrm{Na}^{+}\right.$, $\left.\mathrm{Ca}^{2+}, \mathrm{Mg}^{2+}, \mathrm{Fe}^{2+}\right)$ over anions $\left(\mathrm{H}_{2} \mathrm{PO}_{4}{ }^{-}, \mathrm{Cl}^{-}, \mathrm{SO}_{4}{ }^{2-}\right)$. Consequently $\mathrm{H}^{+}$ is released by the root to maintain electrical neutrality, tending to further decrease the $\mathrm{pH}$. Note that if any nitrogen is taken up as 
$\mathrm{NO}_{3}{ }^{-}$as a result of nitrification of $\mathrm{NH}_{4}{ }^{+}$in the rhizosphere (see below), the net acid-base change is the same because, although the root exports $2 \mathrm{~mol}$ less $\mathrm{H}^{+}$for each mol of $\mathrm{NO}_{3}{ }^{-}$replacing a mol of $\mathrm{NH}_{4}{ }^{+}, 2 \mathrm{~mol}$ of $\mathrm{H}^{+}$are formed in the nitrification of each mol of $\mathrm{NH}_{4}{ }^{+}$. Note also that silicon, which is taken up in large quantities by rice plants, crosses the root as uncharged silicic acid $\left(\mathrm{H}_{4} \mathrm{SiO}_{4}\right)$, whose first dissociation constant $\left(\mathrm{p} K_{1}=9.46\right.$ at $\left.25^{\circ} \mathrm{C}\right)$ is well above typical rhizosphere $\mathrm{pHs}$.

Net changes. The net effects of these processes will depend on their rates versus rates of buffering processes in the soil. In typical, acidic iron toxic soils, the dominant effect is likely to be a decrease in $\mathrm{pH}$ at the root surface due to the large amount of $\mathrm{H}^{+}$produced in $\mathrm{Fe}^{2+}$ oxidation. Begg et al. (1994) found the rhizosphere of rice in an iron toxic soil was acidified by two $\mathrm{pH}$ units from 6.5 in the soil bulk to 4.5 at the root surface. The $\mathrm{pH}$ profile across the rhizosphere will depend on the net rate of $\mathrm{H}^{+}$generation near the root versus the rate at which the $\mathrm{pH}$ change is propagated away through the soil by acid-base transfer. Generally, the main acid-base pairs involved are $\mathrm{H}_{3} \mathrm{O}^{+}-\mathrm{H}_{2} \mathrm{O}$ and $\mathrm{H}_{2} \mathrm{CO}_{3}-\mathrm{HCO}_{3}{ }^{-}: \mathrm{H}_{3} \mathrm{O}^{+}$ions move away from the acidification zone to the soil bulk which has a higher $\mathrm{pH}$, and $\mathrm{HCO}_{3}{ }^{-}$ towards it. The resulting $\mathrm{pH}$ change will be greatest in the $\mathrm{pH}$ range in which $\mathrm{H}_{3} \mathrm{O}^{+}$and $\mathrm{HCO}_{3}{ }^{-}$concentrations are both low (typically
$\mathrm{pH}$ 4.5-6.0, depending on the soil $\mathrm{CO}_{2}$ pressure), as shown in the model calculations in Figure 4. Hence the $\mathrm{pH}$ decrease will be greater in iron toxic soils with already low $\mathrm{pH}$ and relatively low dissolved $\mathrm{CO}_{2}$.

Although the literature generally focuses on iron plaque on root surfaces, most of the $\mathrm{Fe}(\mathrm{OH})_{3}$ is precipitated in the rhizosphere over 1 or $2 \mathrm{~mm}$ from the root surface (Begg et al., 1994). The profile of $\mathrm{Fe}(\mathrm{OH})_{3}$ may be banded in 'Liesegang' rings centred on the root axis. This happens because sorption of $\mathrm{Fe}^{2+}$ on the soil solid - and hence its mobility and rate of oxidation - is $\mathrm{pH}$-dependent, decreasing as the $\mathrm{pH}$ decreases (Kirk, Ahmad, \& Nye, 1990). Therefore, some of the $\mathrm{Fe}^{2+}$ locally diffuses ahead of the oxidation front towards the higher $\mathrm{pH}$ zone, where it is more-strongly sorbed. The total iron profile is therefore banded.

\section{2 | Effects of root-induced changes on nutrient ions in the rhizosphere}

The sharp gradients in redox and $\mathrm{pH}$ across the rhizosphere resulting from the above changes will greatly affect its chemistry and biology, and hence nutrient and toxin uptake by roots. (a)

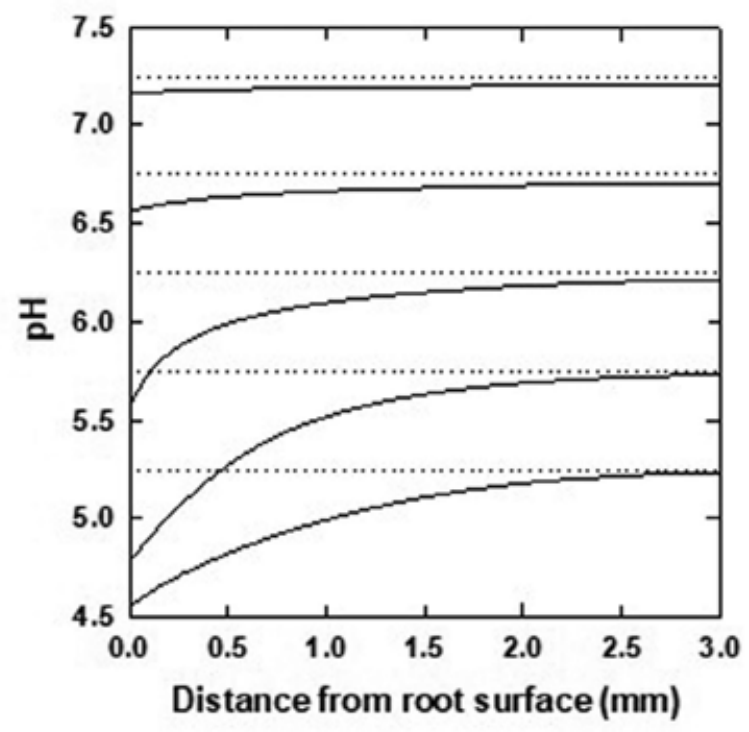

(b)

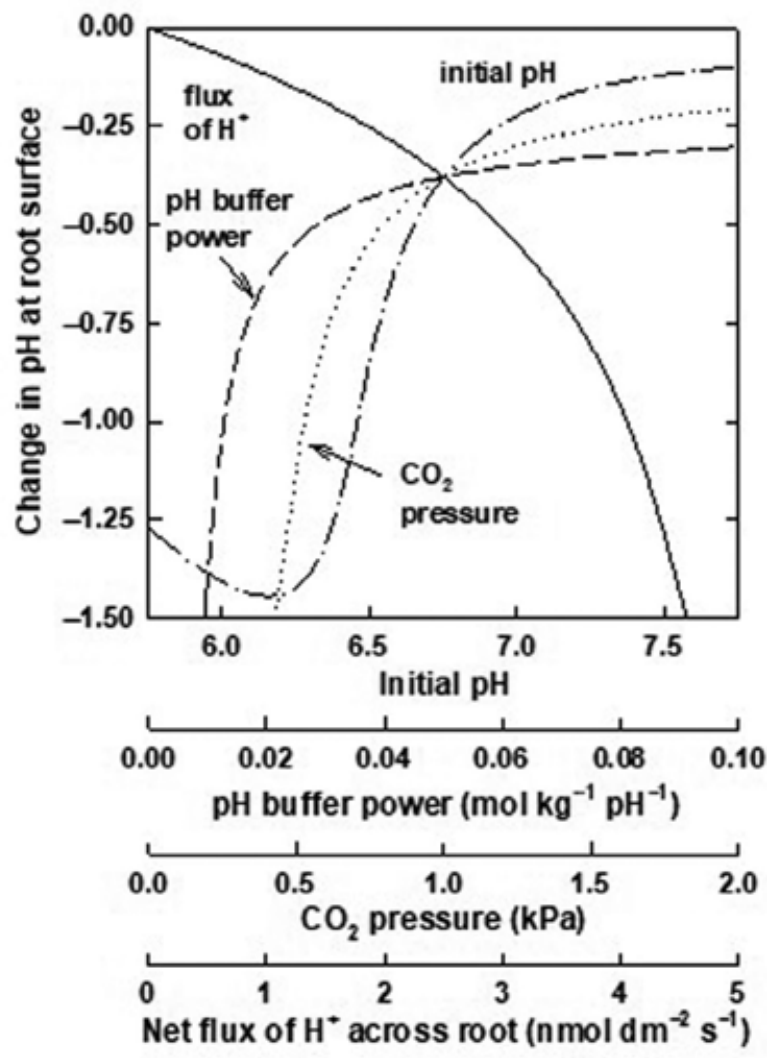

FIGURE 4 Root-induced pH changes in the rhizosphere of rice in iron toxic soil due to the processes shown in Figure 1d (after Kirk, 2004). (a) Calculated $\mathrm{pH}$ profiles in the rhizosphere for a given net flux of $\mathrm{H}^{+}$at different initial soil $\mathrm{pH}$ values (dotted lines). (b) Sensitivity of the $\mathrm{pH}$ change at the root surface to important variables, varied individually from the standard values used for (a) 
Ammonium and nitrate. In some circumstances, a significant part of the nitrogen taken by rice in submerged soils is as $\mathrm{NO}_{3}{ }^{-}$formed by nitrification of $\mathrm{NH}_{4}{ }^{+}$in the rhizosphere (Kirk \& Kronzucker, 2005). Studies on the kinetics of nitrogen uptake and assimilation show that lowland rice is exceptionally efficient in absorbing and assimilating $\mathrm{NO}_{3}{ }^{-}$compared with other plant species (Kronzucker, Glass, Siddiqi, \& Kirk, 2000). This is important because plant growth and yield are generally improved when plants absorb their nitrogen as a mixture of $\mathrm{NO}_{3}{ }^{-}$and $\mathrm{NH}_{4}{ }^{+}$compared with growth on either nitrogen source on its own. In iron toxic soils, rates of nitrification in the rhizosphere are likely to be impeded both by competition with $\mathrm{Fe}^{2+}$ oxidation for root-released $\mathrm{O}_{2}$, and because the rhizosphere is acidified. The proportion of nitrogen absorbed as $\mathrm{NO}_{3}{ }^{-}$will be correspondingly lowered.

There may be a further effect on nitrogen nutrition through an interaction with $\mathrm{CO}_{2}$ venting through the roots (Kirk et al., 2019). Concentrations of dissolved $\mathrm{CO}_{2}$ tend to be smaller in iron toxic soils because of lower rates of microbial respiration (Section 2). But in submerged soils with high dissolved $\mathrm{CO}_{2}$ concentrations, enhanced availability of $\mathrm{CO}_{2}$ in the roots may have a growth-stimulating effect by facilitating anaplerotic production of organic acids for amino acid synthesis (Balkos, Britto, \& Kronzucker, 2010; Britto \& Kronzucker, 2005). This is potentially important because all the $\mathrm{NH}_{4}{ }^{+}$ taken up by rice is assimilated into amino acids in the roots before being transported to the shoots, requiring carbon skeletons (Kronzucker et al., 2000). Rice in iron toxic soil with lower dissolved $\mathrm{CO}_{2}$ concentrations would not benefit from this.

Exchangeable cations. An unexplored consequence of the changes in the rhizosphere, likely to be important in iron toxic soils, is the effect on nutrient cations such as $\mathrm{K}^{+}, \mathrm{Ca}^{2+}$ and $\mathrm{Mg}^{2+}$. The following factors will tend to decrease the concentration of nutrient cations in the soil solution where they are available for uptake by roots.

1. The overall concentration of the solution in a submerged soil is generally controlled by the concentration of bicarbonate $\left(\mathrm{HCO}_{3}{ }^{-}\right)$ anions, formed from dissolved $\mathrm{CO}_{2}$ (Kirk, 2004). If the $\mathrm{pH}$ decreases below about 6.0, the concentration of $\mathrm{HCO}_{3}{ }^{-}$in solution will decrease and so the concentration of cations in solution balanced by the anions must also decrease.

2. A decrease in $\mathrm{pH}$ will also mean the negative charge on soil surfaces will tend to decrease and therefore so will the cation exchange capacity.

3. However, removal of exchangeable $\mathrm{Fe}^{2+}$ as it is oxidized will mean a greater proportion of surface exchange sites is occupied by cations other than $\mathrm{Fe}^{2+}$.

Hence the need to exclude toxic $\mathrm{Fe}^{2+}$ from the root by oxidizing it in the rhizosphere may impair the absorption of nutrient cations by the root. Genotypes with greater iron oxidizing power may make things worse for themselves in iron toxic soils deficient in nutrient cations.

Phosphate and other ions. Phosphate anions may be immobilized on iron plaque and freshly precipitated $\mathrm{Fe}(\mathrm{OH})_{3}$ in the rhizosphere. On the other hand, in phosphate-deficient soils, acid-soluble forms of pin the soil may be solubilized by acidification of the rhizosphere, resulting in increased uptake into roots (Jianguo \& Shuman, 1991; Saleque $\&$ Kirk, 1995). Likewise, acid-soluble forms of zinc may be solubilized in zinc-deficient soils (Kirk \& Bajita, 1995). Possibly uptake of micro-nutrients is enhanced at low levels of iron plaque as a result of a concentrating effect close to absorbing root surfaces (Kirk \& Bajita, 1995; X. K. Zhang, Zhang, \& Mao, 1996; X. Zhang, Zhang, \& Mao, 1999).

\section{3 | Nutrient uptake antagonisms and effects of accompanying anions}

High concentrations of $\mathrm{Fe}^{2+}$ at the root surface may suppress uptake of other cations through antagonistic effects (Wu, Holtkamp, Wairich, \& Frei, 2019). Plants suffer from ionic imbalance through competition between similarly charged cations for binding and carrier sites. In submerged soils, the main anion balancing cations in solution is generally $\mathrm{HCO}_{3}{ }^{-}$(Section 2). A decrease in the rhizosphere $\mathrm{pH}$ as above and consequent decrease in $\mathrm{HCO}_{3}{ }^{-}$concentration means that any $\mathrm{Fe}^{2+}$ entering the root will be accompanied by a proportion of $\mathrm{Cl}^{-}$or $\mathrm{SO}_{4}{ }^{2-}$ rather than $\mathrm{HCO}_{3}{ }^{-}$. If $\mathrm{Fe}^{2+}$ enters with $\mathrm{HCO}_{3}{ }^{-}$, acidity generated in $\mathrm{Fe}^{2+}$ oxidation in the plant will be neutralized by conversion of $\mathrm{HCO}_{3}{ }^{-}$to $\mathrm{CO}_{2}$, which is assimilated or lost. Whereas if it enters with a non-volatile anion, $\mathrm{Fe}^{2+}$ oxidation will produce the equivalent amount of free $\mathrm{H}^{+}$in the plant, with damaging effects on plant tissues (van Mensvoort, Lantin, Brinkman, \& Van Breemen, 1985). We know of no studies exploring this effect. M. Yamauchi (1989) found the severity of iron toxicity in rice in iron toxic soils supplied with $\mathrm{K}_{2} \mathrm{SO}_{4}$ was less than that with $\mathrm{KCl}$, but he attributed the effect to reduction of sulphate to sulphide in the soil and precipitation of $\mathrm{Fe}$ (II) sulphides, lowering the concentration of $\mathrm{Fe}^{2+}$ in solution and hence its uptake.

\section{5 | EFFECTS OF MINERAL NUTRITION ON IRON TOXICITY}

\section{1 | Phosphorus}

Severe phosphorus deficiency is uncommon in lowland rice on young alluvial paddy soils because the soil phosphorus reserves are solubilized in reductive dissolution reactions following soil submergence, and the phosphorus is therefore readily available to the crop. It is much more common in highly weathered soils of inland valleys (Figure 3), which typically have very low extractable phosphorus contents. Phosphorus deficiency interacts with iron toxicity in various ways, tending to exacerbate the direct effects (Sahrawat, 2005). Phosphorus deficiency causes delayed phenological development in rice by up to a month (Dobermann \& Fairhurst, 2000; Vandamme et al., 2018). In soils for which iron toxic conditions develop very slowly following submergence, delayed phenology under phosphorus deficiency may mean the plants are exposed to late-season iron 
toxicity which they would otherwise avoid. On the other hand, under chronic low-level exposure to iron toxicity in acid sandy soils, slower growth might mean less iron is accumulated in the plants and they have longer to acclimatize to it.

Phosphorus deficiency typically results in increased root: shoot ratios, and increased root surface area means increased exposure to $\mathrm{Fe}^{2+}$. Kirk and Du (1997) found phosphorus deficiency in deoxygenated nutrient culture caused increased primary root porosity and an increased proportion of fine lateral roots compared to phosphorussufficient plants, resulting in two-fold greater rates of $\mathrm{O}_{2}$ release per plant. Under iron toxic conditions this could compensate for the greater exposure to $\mathrm{Fe}^{2+}$. Likewise, Fu, Yang, and Shen (2014) found greater root oxidizing capacity under phosphorus deficiency. Phosphorus deficiency also results in impaired cell membrane integrity and therefore loss of organic substrates into the rhizosphere (Rose et al., 2013). This may fuel re-reduction of $\mathrm{Fe}(\mathrm{OH})_{3}$ previously oxidized by $\mathrm{O}_{2}$ release from the root tip zone, so exacerbating $\mathrm{Fe}^{2+}$ toxicity (Benckiser et al., 1984).

\section{2 | Potassium}

The levels of potassium and other cationic nutrients, such as magnesium, also tend to be low in highly-weathered inland valley soils, and deficiencies in rice are common. Potassium deficiency exacerbates iron toxicity through impaired root oxidising power and $\mathrm{Fe}^{2+}$ exclusion, decreased crown root growth and lateral root formation, and decreased $\mathrm{Fe}^{2+}$ storage in roots (Li, Yang \& Luo, 2001; Suriyagoda, Tränkner, \& Dittert, 2020). Potassium deficiency is involved in maintaining normal activity of peroxidase, which breaks down $\mathrm{H}_{2} \mathrm{O}_{2}$ formed in the Fenton reaction in response to excess iron ( $\mathrm{Wu}$ et al., 2017). As with phosphorus deficiency, impaired membrane permeability under potassium deficiency may cause leakage of organic substrates into the rhizosphere, and resulting increased reducing conditions and $\mathrm{Fe}^{2+}$ formation.

The effects of high $\mathrm{Fe}^{2+}$ on rice $\mathrm{K}^{+}$transporters have been investigated. The most important root $\mathrm{K}^{+}$transporter in rice is thought to be OsAKT1 (Golldack, Quigley, Michalowski, Kamasani, \& Bohnert, 2003; J. Li et al., 2014). Genome Wide Association Studies suggest OsAKT1 is associated with regulation of shoot iron concentrations (Matthus et al., 2015). Wu et al. (2019) found increased $\mathrm{Fe}^{2+}$ uptake and root-to-shoot translocation in mutants lacking OsAKT1. They attributed this to greater polarization of the plasma membrane at decreased intracellular $\mathrm{K}^{+}$concentration, resulting in increased $\mathrm{Fe}^{2+}$ transport to the xylem. By corollary, adequate potassium uptake under $\mathrm{Fe}^{2+}$ stress helps regulate root-to-shoot translocation.

\section{3 | Calcium and magnesium}

The factors governing calcium and magnesium deficiencies, their behaviours following soil submergence, and the amounts taken up and removed by rice crops are all similar (Dobermann \&
Fairhurst, 2000). Likewise, the root-induced changes in the soil under iron toxicity should affect calcium and magnesium similarly. Yet deficiencies of magnesium in association with iron toxicity are more common (Figure 3). This may reflect the relative availabilities of soil amendments containing calcium and magnesium. Calcium is applied in phosphate fertilizers and in lime $\left(\mathrm{CaCO}_{3}\right)$ which is more widely available than dolomite $\left(\mathrm{CaCO}_{3}+\mathrm{MgCO}_{3}\right)$ or other magnesium-containing soil amendments, and is widely used to correct acidity in highly weathered soils prone to iron toxicity.

Magnesium deficiency causes a characteristic yellow-orange colouration of the leaves (Figure 1c), as opposed to the bronzing and dark brown streaks of direct iron toxicity (Figure 1b). Low concentrations in the rhizosphere soil solution are induced or exacerbated by high $\mathrm{Fe}^{2+}$ concentrations as a result of the root-induced changes described in Sections 4.1 and 4.2. In deficient soils, symptoms of magnesium deficiency become apparent as the solution $\mathrm{Fe}^{2+}$ concentration increases, and large plants are more seriously affected than small ones, consistent with a greater plant demand for magnesium if other nutrients are less growth-limiting. Magnesium deficiency disrupts $\mathrm{Fe}^{2+}$ storage in leaf cell vacuoles (Kobayashi et al., 2018), and magnesium is involved in defence against damage by reactive oxygen species (Hauer-Jákli \& Tränkner, 2019). A combination of this indirect and direct iron-toxicity produces plants with a wide range of intensities of oranging symptoms and brown streaks on the leaves.

\section{4 | Silicon}

Low silicon levels are also a feature of highly weathered acid soils. Although a 'beneficial' rather than an essential nutrient, it is taken up in large amounts by rice plants, and applications to rice under iron toxic conditions have been found to reduce iron uptake and produce fewer leaf symptoms (Becker, Ngo, \& Schenk, 2020; dos Santos et al., 2020; Dufey, Gheysens, Ingabire, Lutts, \& Bertin, 2014). Its specific role in plant metabolism is not well understood, but probably involves a stabilizing effect on cell walls as an inert deposit in lignified cells, and also by modulating lignin biosynthesis (Broadley et al., 2012). Becker et al. (2020) found decreased $\mathrm{Fe}^{2+}$ uptake on addition of silicon to nutrient cultures, which they attributed to enhanced formation of the root exodermal Casparian strip. Chalmardi, Abdolzadeh, and Sadeghipour (2014) found silicon application improved antioxidant enzyme activity under iron toxic conditions.

\section{6 | IMPLICATIONS FOR RICE BREEDING}

\section{1 | Tolerance within the Oryza gene pool}

Numerous studies have screened sets of varieties or larger germplasm collections in attempts to identify donors for tolerance to iron toxicity, typically using one of two main screening strategies. They may have been conducted in the field in iron toxic hotspots, evaluating grain yield in addition to biomass and leaf symptoms (Melandri et al., 2021; 
Pawar et al., 2021; Sikirou et al., 2018), or they were designed as rapid screens in the nutrient solution to which excess iron had been added at high concentrations for short periods of time (Dufey et al., 2015; Matthus et al., 2015). From these and other studies it can be concluded that ample genetic variation for tolerance to iron toxicity exists within the Oryz sativa gene pool (Matthus et al., 2015; Pawar et al., 2021), and that wild relatives may serve as sources of novel traits enhancing adaptation to iron toxicity (Bierschenk et al., 2020; Wairich et al., 2021).

The indigenous African rice Oryza glaberrima, domesticated from its wild ancestor Oryza barthii about 3,500 years ago (Heuer, Miézan, Sié, \& Gaye, 2004), includes accessions tolerant of a wide range of abiotic stresses, including iron toxicity (Linares, 2002; Melandri et al., 2021; Sié et al., 2012; Sikirou et al., 2018). Sikirou et al. (2018) evaluated more than 2,000 Oryza glaberrima accessions in the Africa Rice Center gene bank at multiple iron toxic hotspots across West Africa, and identified highly tolerant accessions such as TOG 7250-A, TOG 14367, TOG 7206 and TOG 6218-B. Melandri et al. (2021) confirmed the tolerance of some of these accessions. This suggests transferring genes/alleles conferring iron toxicity tolerance from Oryza glaberrima to high-yielding Oryza sativa varieties as a promising breeding strategy. However, spikelet sterility in progenies of Oryza glaberrima and Oryza sativa interspecific crosses has been a major challenge for breeders (Ndjiondjop et al., 2018; Sié et al., 2012).

\section{2 | Breeding strategies}

Iron toxicity in the field is rarely uniform across the large fields needed to evaluate breeding populations, and the severity of stress may vary from year to year. Where such environmental variation reduces the reliability of phenotyping, marker-assisted selection rather than conventional phenotypic selection should be the breeding method of choice. Markers associated with aspects of iron toxicity tolerance exist, identified through GWAS (Matthus et al., 2015; Melandri et al., 2021; Pawar et al., 2021) or through bi-parental QTL mapping populations (Dufey et al., 2015; Rasheed et al., 2020 and references therein). To our knowledge, none of these studies identified loci with large enough effects to be utilized in applied breeding.

In addition, QTL mapping for iron toxicity has been done in the lowland NERICA (NEw RICe for Africa) hybrids of Oryza glaberrima and Oryza sativa to identify markers linked to Oryza glaberrimaderived tolerance loci. Two varieties (NERICA-L19 and NERICA-L43) known to be highly tolerant of iron toxicity (Dramé et al., 2011; Ndjiondjop et al., 2018) have been used to develop mapping populations with recurrent parent IR64; but again, only minor QTLs were identified (Melandri et al., 2021).

Based on QTL mapping, GWAS and transcriptome analysis, it appears that tolerance of iron toxicity in rice is a complex trait controlled by multiple genes distributed throughout the genome (Diop et al., 2020; Melandri et al., 2021; Wairich et al., 2021). In order to successfully identify markers of utility in rice breeding, it may be necessary to break down the complex tolerance response into component traits based on the tolerance mechanisms outlined above, and to develop tailored screening methods for such individual tolerance mechanisms. Hydroponic systems may be suitable for screening for above-ground mechanisms; but below-ground mechanisms require systems that reproduce conditions in the rice rhizosphere in iron toxic soils.

Field screening should take the complexities of below-ground plant-soil interactions into account rather than focusing predominantly on the visible iron toxicity symptoms in leaves. Nozoe, Agbisit, Fukuta, Rodriguez, and Yanagihara (2004) compared selections from the same breeding population made either in the field (for grain yield) or in the nutrient solution (for leaf bronzing) and showed that the yield advantage under iron toxicity of best lines selected in the field was $45 \%$ or more over the sensitive parent IR64, whereas best lines selected in nutrient solution provided no gain in grain yield in the field.

\section{7 | CONCLUSIONS}

1. There is ample variation in tolerance of iron toxicity in both Oryza sativa and Oryza glaberrima gene pools for identifying donors and markers for breeding. However, so far no markers have been identified with large enough effects to be utilized in applied breeding programmes.

2. Germplasm screening is complicated by large genotype-byenvironment effects and weak correlation between visible symptoms and beneficial stress response strategies, including belowground plant-soil interactions.

3. Severe nutrient deficiencies are the norm in most iron toxic soils, and applications of $\mathrm{N}, \mathrm{P}$ and $\mathrm{K}$ fertilizers are essential for reasonable rice yields. Toxicity symptoms become more apparent as nutrient deficiencies are alleviated.

4. Genotypes whose tolerance depends on $\mathrm{Fe}^{2+}$ exclusion by oxidation in the rhizosphere make deficiencies of cationic nutrients (such as potassium and magnesium) worse because of the accompanying acidification of the rhizosphere and resulting impairment of cation mobility. Genotypes with enhanced iron storage in roots and stems may be better suited to such conditions.

5. There has been recent progress in understanding the molecular physiology of tolerance mechanisms, including below-ground processes controlling iron retention in roots and root-shoot transport, as well as above-ground partitioning and tissue tolerance. Each of these interacts in specific ways with nutrient deficiencies.

6. To successfully identify markers for use in breeding, the complex tolerance response should be broken down into component traits based on the tolerance mechanisms outlined above, and tailored screening methods for individual tolerance mechanisms developed.

\section{ACKNOWLEDGMENTS}

This research was funded by a grant from the UK's Biotechnology and Biological Sciences Research Council 'Mechanisms and genetics of iron toxicity tolerance in African rice' (Grant Ref. BB//R020388/1). 


\section{CONFLICT OF INTEREST}

We have no conflicts of interest to declare.

\section{DATA AVAILABILITY STATEMENT}

No new datasets were generated for this article.

\section{ORCID}

Guy J. D. Kirk (D) https://orcid.org/0000-0002-7739-9772

Yoshiaki Ueda (D) https://orcid.org/0000-0002-4304-368X

Vimal K. Semwal (D) https://orcid.org/0000-0002-0903-9492

Matthias Wissuwa (D) https://orcid.org/0000-0003-3505-9398

\section{REFERENCES}

Affholder, M. C., Weiss, D. J., Wissuwa, M., Johnson-Beebout, S., \& Kirk, G. J. D. (2017). Soil $\mathrm{CO}_{2}$ venting as one of the mechanisms for tolerance of $\mathrm{Zn}$ deficiency by rice in flooded soils. Plant, Cell \& Environment, 40, 3018-3030. https://doi.org/10.1111/pce.13069

Ando, T., Yoshida, S., \& Nishiyama, I. (1983). Nature of oxidizing power of rice roots. Plant and Soil, 72, 57-71.

Audebert, A., \& Fofana, M. (2009). Rice yield gap due to iron toxicity in West Africa. Journal of Agronomy and Crop Science, 195, 66-76. https://doi.org/10.1111/j.1439-037X.2008.00339.x

Aung, M. S., Kobayashi, T., Masuda, H., \& Nishizawa, N. K. (2018). Rice HRZ ubiquitin ligases are crucial for the response to excess iron. Physiologia Plantarum, 163, 282-296.

Aung, M. S., \& Masuda, H. (2020). How does rice defend against excess iron?: Physiological and molecular mechanisms. Frontiers in Plant Science, 11, 1102. https://doi.org/10.3389/fpls.2020.01102

Aung, M. S., Masuda, H., Kobayashi, T., \& Nishizawa, N. K. (2018). Physiological and transcriptomic analysis of responses to different levels of iron excess stress in various rice tissues. Soil Science and Plant Nutrition, 64, 370-385.

Balkos, K. D., Britto, D. T., \& Kronzucker, H. J. (2010). Optimization of ammonium acquisition and metabolism by potassium in rice (Oryza sativa L. cv. IR-72). Plant, Cell \& Environment, 33, 23-34.

Bashir, K., Ishimaru, Y., \& Nishizawa, N. K. (2012). Molecular mechanisms of zinc uptake and translocation in rice. Plant and Soil, 361, 189-201.

Becker, M., \& Asch, F. (2005). Iron toxicity in rice-Conditions and management concepts. Journal of Plant Nutrition and Soil Science, 168, 558-573.

Becker, M., Ngo, N. S., \& Schenk, M. K. A. (2020). Silicon reduces the iron uptake in rice and induces iron homeostasis related genes. Scientific Reports, 10, 5079. https://doi.org/10.1038/s41598-020-6171

Begg, C. B. M., Kirk, G. J. D., Mackenzie, A. F., \& Neue, H.-U. (1994). Rootinduced iron oxidation and $\mathrm{pH}$ changes in the lowland rice rhizosphere. New Phytologist, 128, 469-477.

Benckiser, G., Santiago, S., Neue, H. U., Watanabe, I., \& Ottow, J. C. G. (1984). Effect of fertilization on exudation, dehydrogenase activity, iron-reducing populations and $\mathrm{Fe}^{++}$formation in the rhizosphere of rice (Oryza sativa L.) in relation to iron toxicity. Plant and Soil, 79, 305-316.

Bierschenk, B., Tagele, M. T., Ali, B., Ashrafuzzaman, M. D., Wu, L. B., Becker, M., \& Frei, M. (2020). Evaluation of rice wild relatives as a source of traits for adaptation to iron toxicity and enhanced grain quality. PLoS One, 15, e0223086.

Briat, J.-F., Ravet, K., Arnaud, N., Duc, C., Boucherez, J., Touraine, B., ... Gaymard, F. (2010). New insights into ferritin synthesis and function highlight a link between iron homeostasis and oxidative stress in plants. Annals of Botany, 105, 811-822.

Britto, D. T., \& Kronzucker, H. J. (2005). Nitrogen acquisition, PEP carboxylase, and cellular $\mathrm{pH}$ homeostasis: New views on old paradigms. Plant, Cell \& Environment, 38, 1396-1409.
Broadley, M., Brown, P., Cakmak, I., Ma, J. F., Rengel, Z., \& Zhao, F.-J. (2012). Beneficial elements. In P. Marschner (Ed.), Marschner's mineral nutrition of higher plants (3rd ed., pp. 249-268). London: Academic Press.

Bughio, N., Yamaguchi, H., Nishizawa, N. K., Nakanishi, H., \& Mori, S. (2002). Cloning an iron-regulated metal transporter from rice. Journal of Experimental Botany, 53, 1677-1682.

Chalmardi, Z. K., Abdolzadeh, A., \& Sadeghipour, H. R. (2014). Silicon nutrition potentiates the antioxidant metabolism of rice plants under iron toxicity. Acta Physiologiae Plantarum, 36, 493-502.

da Silveira, V. C., Fadanelli, C., Sperotto, R. A., Stein, R. J., Basso, L. A., Santos, D. S., ... Fett, J. P. (2009). Role of ferritin in the rice tolerance to iron overload. Scientia Agricola, 66, 549-555.

Diop, B., Wang, D. R., Dramé, K.-N., Gracen, V., Tongoona, P., ... McCouch, S. R. (2020). Bridging old and new: Diversity and evaluation of high iron-associated stress response of rice cultivated in West Africa. Journal of Experimental Botany, 71, 4188-4200.

Dobermann, A., \& Fairhurst, T. (2000). Rice nutrient disorders and nutrient management. Singapore: Potash and Phosphate Institute, and Manila: International Rice Research Institute.

dos Santos, M. S., Sanglard, L. M., Barbosa, M. L., Namorato, F. A., de Melo, D. C., Franco, W. C., ... DaMatta, F. M. (2020). Silicon nutrition mitigates the negative impacts of iron toxicity in rice photosynthesis and grain yield. Ecotoxicology and Environmental Safety, 189, 10008.

Dramé K.-N., Saito K., Koné B., Chabi A., Dakouo D., Annan-Afful E., ... Sié, M. (2011). Coping with iron toxicity in the lowlands of subSaharan Africa: Experience from Africa Rice Center. Paper presented at: Proceedings of the 2nd Africa Rice Congress, Innovation and Partnerships to Realize Africa's Rice Potential, (Bamako: Africa Rice Center), 191-198.

Dufey, I., Draye, X., Lutts, S., Lorieux, M., Martinez, C., \& Bertin, P. (2015). Novel QTLs in an interspecific backcross Oryza sativa $\times$ Oryza glaberrima for resistance to iron toxicity in rice. Euphytica, 204, 609-625.

Dufey, I., Gheysens, S., Ingabire, A., Lutts, S., \& Bertin, P. (2014). Silicon application in cultivated Rices (Oryza sativa $L$ and Oryza glaberrima Steud) alleviates iron toxicity symptoms through the reduction in iron concentration in the leaf tissue. Journal of Agronomy and Crop Science, 200, 132-142.

Engel, K., Asch, F., \& Becker, M. (2012). Classification of rice genotypes based on their mechanisms of adaptation to iron toxicity. Journal of Plant Nutrition and Soil Science, 175, 871-881.

Finatto, T., Oliveira, A. C., Chaparro, C., Maia, L. C., Farias, D. R., Woyann, L. G., ... Picault, N. (2015). Abiotic stress and genome dynamics: Specific genes and transposable elements response to iron in rice. Rice, 8, 13. https://doi.org/10.1186/s12284-015-0045-6

Frei, M., Tetteh, R. N., Razafindrazaka, A. L., Fuh, M. A., Wu, L.-B., \& Becker, M. (2016). Responses of rice to chronic and acute iron toxicity: Genotypic differences and biofortification aspects. Plant and Soil, 408, 149-161.

Fu, Y. Q., Yang, X. J., \& Shen, H. (2014). The physiological mechanism of enhanced oxidizing capacity of rice (Oryza sativa L.) roots induced by phosphorus deficiency. Acta Physiologiae Plantarum, 36, 179-190.

Golldack, D., Quigley, F., Michalowski, C. B., Kamasani, U. R., \& Bohnert, H. J. (2003). Salinity stress-tolerant and-sensitive rice (Oryza sativa L.) regulate AKT1-type potassium channel transcripts differently. Plant Molecular Biology, 51, 71-81.

Greenway, H., Armstrong, W., \& Colmer, T. D. (2006). Conditions leading to high $\mathrm{CO}_{2}(>5 \mathrm{kPa})$ in waterlogged-flooded soils and possible effects on root growth and metabolism. Annals of Botany, 98, 9-32.

Grillet, L., Lan, P., Li, W., Mokkapati, G., \& Schmidt, W. (2018). IRON MAN is a ubiquitous family of peptides that control iron transport in plants. Nature Plants, 4, 953-963.

Hauer-Jákli, M., \& Tränkner, M. (2019). Critical leaf magnesium thresholds and the impact of magnesium on plant growth and photo-oxidative 
defence: A systematic review and meta-analysis from 70years of research. Frontiers in Plant Science, 10, 766. https://doi.org/10.3389/ fpls.2019.00766

Heuer, S., Miézan, K. M., Sié, M., \& Gaye, S. (2004). Increasing biodiversity of irrigated rice in Africa by interspecific crossing of Oryza glaberrima (Steud.) $\times$ O. sativa indica (L.). Euphytica, 132, 31-40.

Howeler, R. H. (1973). Iron-induced oranging disease of rice in relation to physico-chemical changes in a flooded oxisol. Soil Science Society of America Journal, 37, 898-903.

Inoue, H., Higuchi, K., Takahashi, M., Nakanishi, H., Mori, S., \& Nishizawa, N. K. (2003). Three rice nicotianamine synthase genes, OsNAS1,OsNAS2,and OsNAS3 are expressed in cells involved in longdistance transport of iron and differentially regulated by iron. The Plant Journal, 36, 366-381.

Inoue, H., Kobayashi, T., Nozoye, T., Takahashi, M., Kakei, Y., Suzuki, K., ... Nishizawa, N. K. (2009). Rice OsYSL15 is an iron-regulated iron (III)deoxymugineic acid transporter expressed in the roots and is essential for iron uptake in early growth of the seedlings. Journal of Biological Chemistry, 284, 3470-3479.

Inoue, H., Takahashi, M., Kobayashi, T., Suzuki, M., Nakanishi, H., Mori, S., \& Nishizawa, N. (2008). Identification and localisation of the rice nicotianamine aminotransferase gene OsNAAT1 expression suggests the site of phytosiderophore synthesis in rice. Plant Molecular Biology, 66, 193-203.

Ishimaru, Y., Suzuki, M., Tsukamoto, T., Suzuki, K., Nakazono, M., ... Nishizawa, N. K. (2006). Rice plants take up iron as an $\mathrm{Fe}^{3+}$ -phytosiderophore and as $\mathrm{Fe}^{2+}$. The Plant Journal, 45, 335-346.

Jianguo, H., \& Shuman, L. M. (1991). Phosphorus status and utilization in the rhizosphere of rice. Soil Science, 152, 360-364.

Jugsujinda, A., \& Patrick, W. H., Jr. (1993). Evaluation of toxic conditions associated with oranging symptoms of rice in a flooded Oxisol in Sumatra, Indonesia. Plant and Soil, 152, 237-243.

Kakei, Y., Ishimaru, Y., Kobayashi, T., Yamakawa, T., Nakanishi, H., \& Nishizawa, N. K. (2012). OsYSL16 plays a role in the allocation of iron. Plant Molecular Biology, 79, 583-594.

Kirk, G. J. D. (2003). Rice root properties for internal aeration and efficient nutrient acquisition in submerged soil. New Phytologist, 159, 185-194.

Kirk, G. J. D. (2004). The biogeochemistry of submerged soils. Chichester: Wiley.

Kirk, G. J. D., Ahmad, A. R., \& Nye, P. H. (1990). Coupled diffusion and oxidation of ferrous iron in soils. II. A model of the diffusion and reaction of $\mathrm{O}_{2}, \mathrm{Fe}^{2+}, \mathrm{H}^{+}$and $\mathrm{HCO}_{3}{ }^{-}$in soils and a sensitivity analysis of the model. Journal of Soil Science, 41, 411-431.

Kirk, G. J. D., \& Bajita, J. B. (1995). Root-induced iron oxidation, pH changes and zinc solubilization in the rhizosphere of lowland rice. New Phytologist, 131, 129-137.

Kirk, G. J. D., Boghi, A., Affholder, M. C., Keyes, S. D., Heppell, J., \& Roose, T. (2019). Soil carbon dioxide venting through rice roots. Plant, Cell \& Environment, 42, 3197-3320. https://doi.org/10.1111/pce. 13638

Kirk, G. J. D., \& Du, L. V. (1997). Changes in rice root architecture, porosity, and oxygen and proton release under phosphorus deficiency. New Phytologist, 135, 191-200.

Kirk, G. J. D., \& Kronzucker, H. J. (2005). The potential for nitrification and nitrate uptake in the rhizosphere of wetland plants: A modelling study. Annals of Botany, 96, 639-646.

Kirk, G. J. D., Solivas, J. L., \& Alberto, M. A. (2003). Effects of redox conditions on solute diffusion in soil. European Journal of Soil Science, 54 , 617-624.

Kobayashi, N. I., Ogura, T., Takagi, K., Sugita, R., Suzuki, H., Iwata, R., ... Tanoi, K. (2018). Magnesium deficiency damages the youngest mature leaf in rice through tissue-specific iron toxicity. Plant and Soil, 428 , 137-152.

Kobayashi, T., Itai, R. N., Aung, M. S., Senoura, T., Nakanishi, H., \& Nishizawa, N. K. (2012). The rice transcription factor IDEF1 directly binds to iron and other divalent metals for sensing cellular iron status. Plant Journal, 69, 81-91.

Kobayashi, T., Nagano, A. J., \& Nishizawa, N. K. (2021). Iron deficiencyinducible peptide-coding genes OsIMA1 and OsIMA2 positively regulate a major pathway of iron uptake and translocation in rice. Journal of Experimental Botany, 72, 2196-2211.

Kobayashi, T., Nagasaka, S., Senoura, T., Itai, R. N., Nakanishi, H., \& Nishizawa, N. K. (2013). Iron-binding haemerythrin RING ubiquitin ligases regulate plant iron responses and accumulation. Nature Communications, 4, 2792.

Kobayashi, T., Ogo, Y., Itai, R. N., Nakanishi, H., Takahashi, M., Mori, S., \& Nishizawa, N. K. (2007). The transcription factor IDEF1 regulates the response to and tolerance of iron deficiency in plants. Proceedings of the National Academy of Sciences of the United States of America, 104, 19150-19155.

Koike, S., Inoue, H., Mizuno, D., Takahashi, M., Nakanishi, H., Mori, S., \& Nishizawa, N. K. (2004). OsYSL2 is a rice metal-nicotianamine transporter that is regulated by iron and expressed in the phloem. The Plant Journal, 39, 415-424.

Kosegarten, H., Hoffmann, B., Rroco, E., Grolig, F., Glüsenkamp, K. H., \& Mengel, K. (2004). Apoplastic pH and Felll reduction in young sunflower (Helianthus annuus) roots. Physiologia Plantarum, 122, 95-106.

Kronzucker, H. J., Glass, A. D. M., Siddiqi, M. Y., \& Kirk, G. J. D. (2000). Comparative kinetic analysis of ammonium and nitrate acquisition by tropical lowland rice: Implications for rice cultivation and yield potential. New Phytologist, 145, 471-476.

Li, B., Sun, L., Huang, J., Göschl, C., Shi, W., Chory, J., \& Busch, W. (2019). GSNOR provides plant tolerance to iron toxicity via preventing irondependent nitrosative and oxidative cytotoxicity. Nature Communications, 10, 3896.

Li, G., Kronzucker, H. J., \& Shi, W. (2016a). Root developmental adaptation to Fe toxicity: Mechanisms and management. Plant Signaling \& Behavior, 11, e1117722.

Li, G., Kronzucker, H. J., \& Shi, W. (2016b). The response of the root apex in plant adaptation to iron heterogeneity in soil. Frontiers in Plant Science, 7, 344. https://doi.org/10.3389/fpls.2016.00344

Li, H., Yang, X., \& Luo, A. C. (2001). Ameliorating effect of potassium on iron toxicity in hybrid rice. Journal of Plant Nutrition, 24, 1849-1860. https://doi.org/10.1081/PLN-100107598

Li, J., Long, Y., Qi, G. N., Li, J., Xu, Z. J., Wu, W. H., \& Wang, Y. (2014). The Os-AKT1 channel is critical for $\mathrm{K}^{+}$uptake in rice roots and is modulated by the rice CBL1-CIPK23 complex. The Plant Cell, 26, 3387-3402.

Li, W., Han, Y., Tao, F., \& Chong, K. (2011). Knockdown of SAMS genes encoding S-adenosyl-L-methionine synthetases causes methylation alterations of DNAs and histones and leads to late flowering in rice. Journal of Plant Physiology, 168, 1837-1843.

Linares, O. F. (2002). African rice (Oryza glaberrima): History and future potential. Proceedings of the National Academy of Sciences of the United States of America, 99, 16360-16365.

Majerus, V., Bertin, P., \& Lutts, S. (2009). Abscisic acid and oxidative stress implications in overall ferritin synthesis by African rice (Oryza glaberrima Steud.) seedlings exposed to short term iron toxicity. Plant and Soil, 324, 253-265.

Matthus, E., Wu, L.-B., Ueda, Y., Höller, S., Becker, M., \& Frei, M. (2015). Loci, genes, and mechanisms associated with tolerance to ferrous iron toxicity in rice (Oryza sativa L.). Theoretical and Applied Genetics, 128, 2085-2098.

Melandri, G., Sikirou, M., Arbelaez, J. D., Shittu, A., Semwal, V. K., ... McCouch, S. R. (2021). Multiple small-effect alleles of Indica origin enhance high iron-associated stress tolerance in rice under field conditions in West Africa. Frontiers in Plant Science, 11, 604938.

Mongon, J., Konnerup, D., Colmer, T. D., \& Rerkasem, B. (2014). Responses of rice to $\mathrm{Fe}^{2+}$ in aerated and stagnant conditions: Growth, root porosity and radial oxygen loss barrier. Functional Plant Biology, 41, 922929. https://doi.org/10.1071/FP13359 
Moore, K. L., Chen, Y., van de Meene, A. M. L., Hughes, L., Liu, W., Geraki, T., ... Zhao, F.-J. (2014). Combined NanoSIMS and synchrotron $\mathrm{X}$-ray fluorescence reveal distinct cellular and subcellular distribution patterns of trace elements in rice tissues. New Phytologist, 201, 104-115.

Narteh, N. T., \& Sahrawat, K. L. (1999). Influence of flooding on electrochemical and chemical properties of west African soils. Geoderma, 87, 179-207.

Ndjiondjop, M. N., Semagn, K., Sow, M., Manneh, B., Gouda, A. C., ... Warburton, M. L. (2018). Assessment of genetic variation and population structure of diverse rice genotypes adapted to lowland and upland ecologies in Africa using SNPs. Frontiers in Plant Science, 9, 446.

Nishiuchi, S., Yamauchi, T., Takahashi, H., Kotula, L., \& Nakazono, M. (2012). Mechanisms for coping with submergence and waterlogging in rice. Rice, 5, 2. https://doi.org/10.1186/1939-8433-5-2

Nozoe, T., Agbisit, R., Fukuta, Y., Rodriguez, R., \& Yanagihara, S. (2004). The iron (Fe)-excluding power of rice roots as a mechanism of tolerance of elite breeding lines to iron toxicity. Fisher, T. (ed.) Paper presented at: Proceedings for the 4th International Crop Science Congress, Brisbane, Australia, 26 September - 1 October, 2004.

Nozoye, T., Nagasaka, S., Kobayashi, T., Sato, Y., Uozumi, N., Nakanishi, H., \& Nishizawa, N. K. (2015). The phytosiderophore efflux transporter TOM2 is involved in metal transport in rice. Journal of Biological Chemistry, 290, 27688-27699.

Nozoye, T., Nagasaka, S., Kobayashi, T., Takahashi, M., Sato, Y., Sato, Y., ... Nishizawa, N. K. (2011). Phytosiderophore efflux transporters are crucial for iron acquisition in graminaceous plants. Journal of Biological Chemistry, 286, 5446-5454.

Pawar, S., Pandit, E., Mohanty, I. C., Saha, D., \& Pradhan, S. K. (2021). Population genetic structure and association mapping for iron toxicity tolerance in rice. PLoS One, 16, e0246232.

Ponnamperuma, F. N. (1972). The chemistry of submerged soils. Advances in Agronomy, 24, 29-96.

Quinet, M., Vromman, D., Clippe, A., Bertin, P., Lequeux, H., Dufey, I., ... Lefevre, I. (2012). Combined transcriptomic and physiological approaches reveal strong differences between short- and long-term response of rice (Oryza sativa) to iron toxicity. Plant, Cell \& Environment, 35, 1837-1859.

Rakotoson, T., Ergezinger, L., Rajoandraina, T., Razafimbelo, T., Wu, L.B., \& Frei, M. (2019). Physiological investigations of management and genotype options for adapting rice production to iron toxicity in Madagascar. Journal or Plant Nutrition and Soil Science, 182, 145-155. https://doi.org/10.1002/jpln.201800621

Rasheed, A., Hassan, M. U., Aamer, M., Bian, J. M., Xu, Z. R., He, X. F., \& Wu, Z. M. (2020). Iron toxicity, tolerance and quantitative trait loci mapping in rice: A review. Applied Ecology and Environmental Research, 18, 7483-7498.

Rodenburg, J., Zwartb, S. J., Kiepe, P., Narteh, L. T., Dogbe, W., \& Wopereis, M. C. S. (2014). Sustainable rice production in African inland valleys: Seizing regional potentials through local approaches. Agricultural Systems, 123, 1-11.

Rose, T. J., Impa, S. M., Rose, M. T., Pariasca-Tanaka, J., Mori, A., Heuer, S., ... Wissuwa, M. (2013). Enhancing phosphorus and zinc acquisition eefficiency in rice: A critical review of root traits and their potential utility in rice breeding. Annals of Botany, 112, 331-345.

Sahrawat, K. L. (2000). Elemental composition of the rice plant as affected by iron toxicity under field conditions. Communications in Soil Science and Plant Analysis, 31, 2819-2827.

Sahrawat, K. L. (2005). Iron toxicity in wetland rice and the role of other nutrients. Journal of Plant Nutrition, 27, 1471-1504.

Sahrawat, K. L., Mulbah, C. K., Diatta, S., Delaune, R. D., Patrick, D., Jr., Singh, B. N., \& Jones, M. P. (1996). The role of tolerant genotypes and plant nutrients in the management of iron toxicity in lowland rice. Journal of Agricultural Science, 126, 143-149.

Saleque, M. A., \& Kirk, G. J. D. (1995). Root-induced solubilization of phosphate in the rhizosphere of lowland rice. New Phytologist, 129, 325-336.

Selote, D., Samira, R., Matthiadis, A., Gillikin, J. W., \& Long, T. A. (2015). Iron-binding e3 ligase mediates iron response in plants by targeting basic helix-loop-helix transcription factors. Plant Physiology, 167, 273-286.

Sié, M., Sanni, K., Futakuchi, K., Manneh, B., Mandé, S., Vodouhe, R., ... Traore, K. (2012). Towards a rational use of African rice (Oryza glaberrima Steud.) for breeding in sub-Saharan Africa. Genes, Genomes, and Genomics, 6, 1-7.

Sikirou, M., Saito, K., Achigan-Dako, E. G., Dramé, K. N., Adam, A., \& Venuprasad, R. (2015). Genetic improvement of iron toxicity tolerance in rice-Progress, challenges and prospects in West Africa. Plant Production Science, 18, 423-424.

Sikirou, M., Shittu, A., Konaté, K. A., Maji, A. T., Ngaujah, A. S., Sanni, K. A., ... Venuprasad, R. (2018). Screening African rice (Oryza glaberrima) for tolerance to abiotic stresses: I. Fe toxicity. Field Crops Research, 220, 3-9. https://doi.org/10.1016/j.fcr.2016.04.016

Stein, R. J., Ricachenevsky, F. K., \& Fett, J. P. (2009). Differential regulation of the two rice ferritin genes (OsFER1 and OsFER2). Plant Science, 177, 563-569.

Stein, R. J., Ricachenevsky, F. K., \& Fett, J. P. (2014). Iron toxicity in fieldcultivated rice: Contrasting tolerance mechanisms in distinct cultivars. Theoretical and Experimental Plant Physiology, 26, 135-146.

Suriyagoda, L. D., Tränkner, M., \& Dittert, K. (2020). Effects of potassium nutrition and water availability on iron toxicity of rice seedlings. Journal of Plant Nutrition, 43, 2350-2367.

van Mensvoort, M. E., Lantin, R. S., Brinkman, R., \& Van Breemen, N. (1985). Toxicities of wetland soils. In Wetland soils: Characterization, classification, and utilization (pp. 123-138). Manila: International Rice Research Institute.

Vandamme, E., Ahouanton, K., Mwakasege, L., Mujuni, S., Mujawamariya, G., Kamanda, J., ... Saito, K. (2018). Phosphorus microdosing as an entry point to sustainable intensification of rice systems in sub-Saharan Africa. Field Crops Research, 222, 39-49.

Wairich, A., de Oliveira, B. H. N., Wu, L. B., Murugaiyan, V., MargisPinheiro, M., Fett, J. P., ... Frei, M. (2021). Chromosomal introgressions from Oryza meridionalis into domesticated rice Oryza sativa result in iron tolerance. Journal of Experimental Botany, 72, 2242-2259.

Wu, L.-B., Holtkamp, H., Wairich, A., \& Frei, M. (2019). Potassium ion channel gene OsAKT1 affects iron translocation in rice plants exposed to iron toxicity. Frontiers in Plant Science, 10, 579. https://doi.org/10. 3389/fpls.2019.00579

Wu, L.-B., Shhadi, M. Y., Gregorio, G., Matthus, E., Becker, M., \& Frei, M. (2014). Genetic and physiological analysis of tolerance to acute iron toxicity in rice. Rice, 7, 8. Retrieved from www.thericejournal.com/ content/7/1/8

Wu, L.-B., Ueda, Y., Lai, S. K., \& Frei, M. (2017). Shoot tolerance mechanisms to iron toxicity in rice (Oryza sativa L.). Plant, Cell \& Environment, 40, 570-584.

Yamanouchi, M., \& Yoshida, S. (1981). Physiological mechanisms of rice's tolerance for iron toxicity. Paper presented at the IRRI Saturday Seminar, June 6, 1981. Manila: International Rice Research Institute.

Yamauchi, M. (1989). Rice bronzing in Nigeria caused by nutrient imbalances and its control by potassium sulfate application. Plant and Soil, 117, 275-286.

Yamauchi, M., \& Peng, X. X. (1995). Iron toxicity and stress-induced ethylene production in rice leaves. Plant and Soil, 173, 21-28.

Yamauchi, T., Colmer, T. D., Pederson, O., \& Nakazono, M. (2018). Regulation of root traits for internal aeration and tolerance of waterloggingflooding stress. Plant Physiology, 176, 118-1130. 
Yoshida, S. (1981). Fundamentals of rice crop science. Manila: International Rice Research Institute.

Zhang, H., Li, Y., Yao, X., Liang, G., \& Yu, D. (2017). Positive regulator of iron homeostasis1, OsPRI1, facilitates iron homeostasis. Plant Physiology, 175, 543-554.

Zhang, X., Zhang, F., \& Mao, D. (1999). Effect of iron plaque outside roots on nutrient uptake by rice (Oryza sativa L.): Phosphorus uptake. Plant and Soil, 209, 187-192.

Zhang, X. K., Zhang, F. S., \& Mao, D. R. (1996). Effect of root iron plaque on zinc uptake by rice plant. Chinese Acta Applied Ecology, 7, 262-266.

Zhang, Y., Xu, Y. H., Yi, H. Y., \& Gong, J. M. (2012). Vacuolar membrane transporters OsVIT1 and OsVIT2 modulate iron translocation between flag leaves and seeds in rice. Plant Journal, 72, 400-410.
Zhang, Y., Zheng, G. H., Liu, P., Song, J. M., Xu, G. D., \& Cai, M. Z. (2011). Morphological and physiological responses of root tip cells to $\mathrm{Fe}^{2+}$ toxicity in rice. Acta Physiologiae Plantarum, 33, 683-689.

How to cite this article: Kirk, G. J. D., Manwaring, H. R., Ueda, Y., Semwal, V. K., \& Wissuwa, M. (2022). Below-ground plantsoil interactions affecting adaptations of rice to iron toxicity. Plant, Cell \& Environment, 45, 705-718. https://doi.org/10.1111/ pce.14199 